\title{
Northern Long-eared Bat, Myotis septentrionalis (Chiroptera: Vespertilionidae), on Prince Edward Island: First Records of Occurrence and Over-Wintering
}

\author{
JenNifer A. Brown ${ }^{1}$, Donald F. McAlpine ${ }^{2}$, and Rosemary Curley ${ }^{3}$ \\ ${ }^{1}$ University of Guelph, Department of Animal and Poultry Science, Guelph, Ontario N1G 2W1 Canada \\ ${ }^{2}$ New Brunswick Museum, 277 Douglas Avenue, Saint John, New Brunswick E2K 1E5 Canada (author to whom correspondence \\ should be addressed; e-mail: donald.mcalpine@nbm-mnb.ca) \\ ${ }^{3}$ Forests, Fish and Wildlife Division, Prince Edward Island Department of Environment, Energy, and Forestry, P.O. Box 2000, \\ Charlottetown, Prince Edward Island C1A 7N8 Canada
}

Brown, Jennifer. A., Donald F. McAlpine, and Rosemary Curley. 2007. Northern Long-eared Bat, Myotis septentrionalis (Chiroptera: Vespertilionidae), on Prince Edward Island: first records of occurrence and over-wintering. Canadian Field-Naturalist 121(2): 208-209.

First occurrence of the Northern Long-eared Bat, Myotis septentrionalis, on Prince Edward Island is reported. A mixedspecies hibernaculum of M. septentrionalis and the Little Brown Bat, M. lucifugus, is also described from southeastern Prince Edward Island. This is the first record of bats over-wintering in the province and the first time either species has been reported making use of a building as a hibernaculum.

Key Words: Little Brown Bat, Myotis lucifugus, Northern Long-eared Bat, Myotis septentrionalis, Prince Edward Island, distribution, hibernaculum.

The bats of Prince Edward Island are poorly known. Although seven species have been recorded from the adjacent mainland of New Brunswick and Nova Scotia (van Zyll de Jong 1985), only the Little Brown Bat (Myotis lucifugus) and Hoary Bat (Lasiurus cinereus) are known from the Island (van Zyll de Jong 1985; McApine et al. 2002). Cameron (1958) reported a sighting which he believed to be a Red Bat (Lasiurus borealis) near coastal Fortune Bridge, Kings County, Prince Edward Island $\left(46^{\circ} 21^{\prime} 23^{\prime \prime N} 62^{\circ} 29^{\prime} 57^{\prime \prime W}\right)$ on 7 June 1954 , but this species remains unconfirmed on the Island. Neither have any bat species been documented to hibernate on Prince Edward Island. Here we document the first occurrence of the Northern Long-eared Bat (Myotis septentrionalis) from the province and report a mixed-species hibernaculum of $M$. lucifugus and M. septentrionalis from southeastern Prince Edward Island.

On 24 September 1988, two bats retrieved by a house cat (Felis domesticus) were collected in Breadalbane, Queens County, Prince Edward Island $\left(46^{\circ} 21^{\prime} 23^{\prime \prime} \mathrm{N} 63^{\circ} 29^{\prime} 57^{\prime \prime} \mathrm{W}\right)$ by JAB and subsequently identified as $M$. septentrionalis. These specimens, deposited in the Canadian Museum of Nature (CMN), include a male (CMN 52612) and a female (CMN 52613). Measurements for both bats (M (male), TL (total length) $85 \mathrm{~mm}, \mathrm{~T}$ (tail) $37 \mathrm{~mm}, \mathrm{HF}$ (hind foot) $10 \mathrm{~mm}$; F (female), TL $90 \mathrm{~mm}$, T $36 \mathrm{~mm}$, HF $10 \mathrm{~mm}$ ) fall within the range for the species presented by van Zyll de Jong (1985).

On or about 10 January 1989 a commercial pest control officer removed about 800 bats, both Little Brown and Northern Long-eared bats, from the basement of a home at Culloden, Queens County, Prince Edward Island $\left(46^{\circ} 0^{\prime} 58^{\prime \prime} \mathrm{N} 62^{\circ} 42^{\prime} 8 \mathrm{~W}\right.$; reported in the media as
Murray River, the larger nearby community). All bats were destined to be incinerated. However, DFM was able to secure 781 of these bats alive and an unsuccessful attempt was made to maintain them in a state of torpor over the winter with the intention of spring release. Various media reports suggest that the hibernaculum contained 1500 bats (Anonymous 1989*; Cody $1989 \mathrm{a}^{*}, \mathrm{~b}^{*}$; White 1989*). However, communication with the pest control officer (personal communication to DFM) confirmed that all hibernating bats observed were removed. Information presented here is based on an examination of all 781 bats, apparently the contents of virtually the entire hibernaculum. We visited the hibernaculum site on 29 November 1990 and found only two torpid female $M$. septentrionalis, clinging to wooden floor joists. A voucher series of both species from the site have been deposited in the mammal collection of the New Brunswick Museum.

The hibernation site was the unheated basement of an occupied home, built about 1980. The house had been recently re-occupied following a 3-5 year vacancy (resident personal communication to DFM). The basement had an earthen floor and island stone and mortar foundation walls with inside dimensions about $11 \times 8 \mathrm{~m}$ and a ceiling height of 1-2 m. Entry to the basement was via a trap door on the first floor. Air temperature in the hibernaculum recorded on the night of $29 \mathrm{No}-$ vember 1990 was $11.3^{\circ} \mathrm{C}$. This hibernation temperature, while above the mode of $6^{\circ} \mathrm{C}$ for vespertilionids, falls within the range of $-4^{\circ}$ to $13^{\circ} \mathrm{C}$ and $0.6^{\circ} \mathrm{C}$ to $13.9^{\circ} \mathrm{C}$ reported for Little Brown and Northern Longeared bats; respectively (Webb et al. 1996). The hibernaculum was dominated by the Little Brown Bat $(82.6 \%)$; with smaller numbers of the Northern Longeared $(17.4 \%)$. In both species sex ratios were slightly 
female biased (62.1\% and $57.1 \%$ in M. lucifugus and M. septentrionalis, respectively). We also assessed reproductive status by dissection of all Northern Long-eared Bats following the criteria and terminology of Sluiter and Bouman (1951), Sluiter (1954, 1961), and Racey (1974), with the following results: males; $5.9 \%$ sexually immature, $94.1 \%$ sexually mature; females; $17.5 \%$ nulliparous, $14.2 \%$ nonparous, $68.3 \%$ parous.

The Northern Long-eared Bat is widespread across Atlantic Canada (van Zyll de Jong 1985). Although less abundant, apparently, in the region than the Little Brown Bat, the presence of the Northern Long-eared Bat on Prince Edward Island is not unexpected. Culloden and Breadalbane are $67 \mathrm{~km}$ straight-line distance apart, suggesting $M$. septentrionalis may be widespread in the province. Conversely, the discovery of large numbers of hibernating bats on the Island was unanticipated. The province is underlain largely by Permian sandstones, siltstone and glystone (van de Poll 1983) and we are aware of no natural caves or abandoned mines on the Island that might provide suitable hibernacula. The closest natural caves serving as bat hibernacula occur in adjacent New Brunswick and Nova Scotia (McAlpine 1983; Mosely 2007). Fenton and Barclay (1980) were unable to locate any records of Little Brown Bats hibernating in buildings. Likewise, the Northern Long-eared has previously only been recorded hibernating in caves and mines (van Zyll de Jong 1985). Both these species of Myotis may be more flexible in their hibernation requirements than the literature suggests, being able to rapidly exploit suitable artificial hibernacula where present.

\section{Acknowledgments}

We are grateful to the late C. G. van Zyll de Jong, both for his encouragement and for confirming the identity of the two bats collected at Breadalbane. We also thank the resident of Culloden who so graciously allowed us access to her home, and Earl Peterson, Maritime Varmint and Rodent Control, for agreeing to make the bats removed from this home available to DFM.

Documents Cited [marked* in text]

Anonymous. 1989. Going batty (photo with caption). The Telegraph Journal, Saint John, New Brunswick, 14 January 1989, Page 1.
Cody, J. 1989a. P.E.I. bats likely to become "ex-bats": people curious about their fate. The Guardian, Charlottetown, Prince Edward Island, 19 January 1989, Page 6.

Cody, J. 1989b. Bat removal poses question of animal's right to live. The Evening Patriot, Charlottetown, Prince Edward Island, 18 January 1989, Page 3.

White, D. 1989. Bats take up residence in Culloden basement. The Times-Transcript, Moncton, New Brunswick.

\section{Literature Cited}

Cameron, A. W. 1958. Mammals of the islands in the Gulf of St. Lawrence. Bulletin 154, National Museum of Canada, Ottawa.

Fenton, M. B., and M. R. Barclay. 1980. Myotis lucifugus. Mammalian Species 142: 1-8.

McAlpine, D. F. 1983. Status and conservation of solution caves in New Brunswick. New Brunswick Museum. Publications in Natural Science (1). 28 pages.

McAlpine, D. F, F. Muldoon, and A. I. Wandeler. 2002. First record of the Hoary Bat, Lasiurus cinereus (Chiroptera: Vespertilionidae), from Prince Edward Island. Canadian Field-Naturalist 116: 124-125.

Mosely, M. 2007. Acadian biospeleology: composition and ecology of cave fauna of Nova Scotia and southern New Brunswick, Canada. International Journal of Speleology 36: 1-21.

Racey, P. A. 1974. Ageing and assessment of reproductive status of Pipistrellus bats, Pipistrellus pipistrellus. Journal of Zoology 173: 264-271.

Sluiter, J. W. 1954. Sexual maturity in bats of the genus Myotis II. Females of M. mystacinus and supplementary data on female $M$. myotis and M. emarginatus. Koninklijke Nederlandsche Academie van Wetenschappen 57: 696-700.

Sluiter, J. W. 1961. Sexual maturity in males of the bat Myotis myotis. Koninklijke Nederlandsche Academie van Wetenschappen 64: 243-249.

Sluiter, J. W., and M. Bouman. 1951. Sexual maturity in bats of the genus Myotis I. Size and histology of the reproductive organs during hibernation in connection with age and wear of the teeth in female Myotis myotis and Myotis emarginatus. Koninklijke Nederlandsche Academie van Wetenschappen 54: 595-603.

van de Poll, H. W. 1983. Geology of Prince Edward Island. Province of Prince Edward Island, Department of Energy and Forestry. Report 83-1.

van Zyll de Jong, C. G. 1985. Handbook of Canadian Mammals 2: Bats. National Museum of Natural Sciences, Ottawa.

Webb, P. I, J. R. Speakman, and P. A. Racey. 1996. How hot is a hibernaculum? A review of the temperature at which bats hibernate. Canadian Journal of Zoology 74: 761-765.

Received 9 May 2007

Accepted 14 January 2008 